\title{
Nutritive Assessment of Composite Flour Biscuit Incorporated with Herbal Plant Powder
}

\author{
N.A.I.S. Dias * and G.M.W.R. Bandara
}

\section{ABSTRACT}

A cookie is a baked product, which can be prepared by using wheat flour with nonwheat materials enriched with nutritional value. The study aims to formulate herbal cookies incorporating Asparagus racemosus and Aerva lanata stem and leaf powder enriched with mungbean (Vigna radiata) and wheat flour. Each of the herbal plant powder and flour mixture was formulated at a ratio of $1: 1$ by drying and grinding into a fine powder. Three different cookie formulas by varying combinations of plant powder and flour mixture were evaluated based on the 5point hedonic scale on sensory attributes by a 30 member untrained panel. According to the results of sensory evaluation, the sample enriched with $4 \%$ plant powder and $55 \%$ flour mixture was accepted. The phytochemical analysis indicated the presence of secondary metabolites including Alkaloids, Saponins, Flavonoids, Tannins, Phenols, Terpenoids, Glycosides and Steroid in the accepted cookie sample. The cookies were rich in carbohydrate $(59.3 \%)$, fat (14.3\%), protein $(13.4 \%)$ and the calculated energy value was 419.5 kcal. Peroxide value and acid value of stored cookies were lower than the maximum recommended level. The IC50 value for the methanol extract of the herbal cookies was $16.69 \pm 0.88 \mathrm{mg} / \mathrm{ml}$. The bacterial count of cookies was $6.0 \times 10^{2} \mathrm{CFU} / \mathrm{g}$

Faculty of Science, Horizon Campus, Malabe, Sri Lanka.

*diasisurusampath@gmail.com http://orcid.org/0000-0002-3047-4990

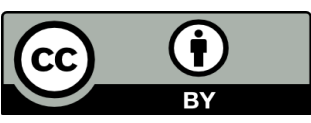

This article is published under the Creative Commons Attribution License (CC 4.0),

which permits unrestricted use, distribution, and reproduction in any medium provided the original work is properly cited. after 6 weeks of storage and this was well below the safe level of $1 \times 10^{4} \mathrm{CFU} / \mathrm{g}$. There was no yeast and mold growth observed during the storage. Overall analysis proved that herbal cookies were acceptable for human consumption after storing it under room temperature within six weeks.

Keywords: Antioxidants, Herbal cookies, Herbal plant powder, Mungbean flour, Sensory evaluation

\section{INTRODUCTION}

In the last few years there has been an exponential growth in the field of herbal medicine and functional foods. The population everywhere desires to eat a healthier diet without changing their conventional dietary patterns (Thorat et al., 2017). Sri Lankan tradition is steeped with natural medicine that is enjoyed as food in our daily life as sages of ancient times recognized the benefits of valuable herbal plants such as Hathawariya and Polpala. 'Hathawariya' (Asparagus racemosus) and 'Polpala' (Aerva lanata) are common medicinal plants throughout Sri Lanka (Robert, 1998). Although these herbal plants are common, the plants are not much incorporated into instant foods such as cookies or biscuits apart from herbal biscuits made using few plants such as curry leaves (Murraya koenigii). On the other hand herbal porridge is the most common food item in which these plants are applied with a number of nutritive properties (Gunasekera, 2015). 
'Hathawariya'

(Asparagus

racemosus) is a species of asparagus with a long history of use in India and other parts of Asia as folk medicine. Many medicinal qualities of this plant have been associated with phytonutrients present in its roots, and especially one type of phytonutrients called saponins. Saponins in food have repeatedly been shown to have anti-inflammatory and anti-cancer properties, and their intake has also been associated with improved blood pressure, improved blood sugar regulation, and better control of blood fat levels. And also almost all parts of both Asparagus racemosus and Aerva lanata plants can be consumed as food (Gunasekera, 2015).

A cookie is small sweet, usually containing refined flour, eggs, sugar, and either butter or fat. It may include other ingredients such as raisins, oats, chocolate chips, or nuts. There are minor differences between cookies and biscuits in the percentage of raw materials, methods and the external and internal qualities. The biscuits or cookies are prepared either by machine or manually. Cookies can be classified as ready to eat and convenient foods. They are popular for morning and evening tea-time snacks. Low-cost nutritive cookies made of herbal components plant powder is an alternative option to rejuvenate immunity (Upadhyay et al., 2017).

Processed food has a great shelf life and easy to carry in traveling, office and house. Working families have alternate options for readymade food to fulfill their nutritional requirements. Generally, bakery food is high in starch calories. Herbs based cookies have an alternate option to replace conventional cookies. Cookies are a well shelf-stable bakery product. The economic importance of cookies is higher in all areas. Conventional processed foods have been replaced by functional processed food (Upadhyay et al., 2017).

One of the alternatives to overcome these problems is producing an herbal cookie using herbal plants consisting of natural ingredients. Thus, producing that kind of fully nutritional cookies is a good chance for consumers to save time for cooking and money. Also, it will give instant herbal food with high nutritional value, enriched with herbal value and beneficial health effects such as anticancer, decreasing high blood pressure, etc. Same time, it is easy to eat at any time and at any place where most of the children usually like to eat. Therefore, the present study aims to produce herbal cookies incorporating Asparagus racemosus and Aerva lanata plant powder enriched with mungbean flour, formulated based on the optimal level of selected ingredients for the acceptable level.

\section{MATERIALS AND METHODS Formulating Plant Powder and Mungbean Flour}

Wheat flour, mungbean, margarine, sugar, milk, water, salt, baking powder, vanilla and young leaves and stems of Aerva lanata and Asparagus racemosus were applied for the sample preparation. 
Approximately, equal amounts of dried plant parts were taken and were ground using a laboratory-scale grinder into a fine powder. The plant powder was stored in an airtight bottle in a dry place under room temperature (Ikechukwu et al., 2017). Collected $250 \mathrm{~g}$ of mungbean were washed, de-stoned, sun-dried and roasted. Then roasted grains were ground using a laboratory-scale grinder to produce flour and the mungbean flour was stored in an airtight bottle under room temperature for preservation.

\section{The Methodology of Producing Herbal \\ Cookies}

Each ingredient (wheat flour, mungbean flour, plant powder, margarine, sugar) was measured into a bowl. Approximately equal amounts of mung bean flour and wheat flour were added to the bowl. The ingredients were beaten and mixed by using a food mixer. The mixture was then kneaded until it became dough. The dough was rolled and flattened into a uniform thickness of about $3.5 \mathrm{~mm}$ before cutting out to shapes using a hand-cutter. It was baked at $170^{\circ} \mathrm{C}$ for 30 minutes in the oven. After baking, the cookies were cooled to room temperature, packed in low-density polyethylene (LDPE) bags and sealed in a plastic transparent container (Thorat et al., 2017). Three different treatments (T1, T2 and T3) for sensory evaluation were prepared by varying the quantities of the flour mixture and plant powder mixture (Aerva lanata and Asparagus racemosus) (Table 1). Results of the sensory evaluation were analyzed using Kruskal-Wallis nonparametric method in MINITAB statistical software version 18.1. As per the results, the best herbal cookie formula was selected for further development of the study.

\section{Determination of Physio- Chemical Characteristics}

\section{Phytochemical Screening}

The methanol extract of the product was obtained using the method described by Jayashree et al. (2013). The presence of saponins, flavonoids, steroids, terpenoids,

Table 1: Formulation of composite ingredients (\%) of cookies in three treatments

\begin{tabular}{lccc}
\hline \multicolumn{1}{c}{ Ingredients } & T1 & T2 & T3 \\
\hline $\begin{array}{l}\text { Flour mixture } \\
\text { (Mungbean + Wheat }\end{array}$ & $53.0 \%$ & $54.0 \%$ & $55.0 \%$ \\
flour) & & & \\
$\begin{array}{l}\text { Plant powder } \\
\text { mixture }\end{array}$ & $6.0 \%$ & $5.0 \%$ & $4.0 \%$ \\
Sugar & & & \\
Margarine & $20.0 \%$ & $20.0 \%$ & $20.0 \%$ \\
Miscellaneous* & $20.0 \%$ & $20.0 \%$ & $20.0 \%$ \\
\hline
\end{tabular}

*salt, baking powder and vanilla 
glycosides, phenols, tannins and alkaloids was determined using the method described by Oeung et al. (2017). The presence of anthraquinones was determined using the method described by Jayashree et al. (2013)

\section{pH Value}

The $\mathrm{pH}$ values of the cookies were determined by suspending $10 \mathrm{~g}$ of cookie sample in $100 \mathrm{ml}$ of distilled water in $250 \mathrm{ml}$ beaker using digital scale $\mathrm{pH}$ meter under room temperature $\left(25^{\circ} \mathrm{C}\right)$. This procedure was triplicated within a week and the average $\mathrm{pH}$ value was calculated. After that, the same sample was analyzed for three weeks.

\section{Titratable Acidity and Peroxide Value}

Titratable acidity of the product was determined using the method described by Kajala et al. (2015). $\mathrm{NaOH}$ solution was titrated against the water extract of cookies and the titration was triplicated. The peroxide value of the product was determined using the AOAC. (2006).

\section{Estimation of Nutritional Composition}

The moisture content of the herbal cookies was determined using the Oven Drying Method described by ISO 712: 2007 (Sri Lanka Standards, 2007). The total ash content of the herbal cookies was determined using the Dry Ash Method described by ISO 1575:2007 (Sri Lanka Standards, 2007). The water-soluble ash content of the herbal cookies was determined using the ISO 1576: 1988 (Sri
Lanka Standards, 1988). The crude fat content of the herbal cookies was determined using the solvent extraction method described by Kirk et al. (1991). The crude fiber content of the herbal cookies was determined according to AOAC (2006) method. The crude protein content of the herbal cookies was determined according to the Kjeldahl method described by SLS 735: 2012. The carbohydrate content of the herbal cookies was determined according to the Nitrogen free method described by AOAC (2006), i.e. \% Carbohydrate (NFE) $=100-(\mathrm{M}+\mathrm{P}+\mathrm{F}+\mathrm{A}+\mathrm{F} 2)$, where, $\mathrm{M}=$ Moisture, $\mathrm{P}=$ Protein, $\mathrm{F}=$ Fat, $\mathrm{A}=$ Ash, $\mathrm{F} 2$ $=$ Crude fibre.

\section{Calorific Value}

The caloric value (EV) was calculated using the method described by Grah et al. (2014), i.e. $\% \mathrm{EV}=(\%$ Protein $\times 4)+(\%$ Lipid $\times 9)+(\%$ Carbohydrate $\times 4)$.

\section{Determination of Antioxidant Activity (DPPH Radical Scavenging Assay)}

The antioxidant capacity of the cookie extracts was studied through the evaluation of the free radical-scavenging effect on the DPPH radical. The determination was based on the method proposed by Uthumporn et al. (2014) with modifications using the following equation, i.e.

$$
\text { Inhibition } \%=\frac{\left(A_{0}-A\right)}{A_{0}} \times 100 \% \text {, }
$$

where ' $\mathrm{A}_{0}$ ' is the absorbance of the control (without sample) and ' $\mathrm{A}$ ' is the absorbance of the sample. 
The scavenging ability of the samples was expressed as $\mathrm{IC}_{50}$ value which is the effective concentration where $50 \%$ of the DPPH radicals were scavenged. The sample concentration providing 50\% inhibition (IC50) was calculated from the graph of inhibition percentage against sample concentration.

\section{Evaluation of Microbial Stability of the Cookies}

Total Plate Count and Enumeration of Yeast and Mold

The total plate count was determined according to the pour plate method described by ISO 4833: 2013 (Sri Lanka Standards, 2013). The yeast and mold count was determined according to the pour plate method described by ISO 21527-2: 2008 (Sri Lanka Standards, 2008).

\section{RESULTS AND DISCUSSION \\ Overall Comparison of Sensory Evaluation}

For three different herbal cookie formulae, from Kruskal- Wallis test conducted with five-point hedonic scale sensory evaluation, $\mathrm{H}_{\text {stat }}$ value for smoothness and crunchiness were larger than $H_{\text {table }}$ values where significant differences were at $p<0.05$. There were significant differences among treatments for smoothness and crunchiness while, color, sweetness, mouth-feel and overall likeness were not significantly different among the treatments. However, fondness for crunchiness, mouthfeel and overall likeness were relatively higher in the treatment T3. Therefore, T3 was selected as the most preferable herbal cookie formula out of the three treatments (Figure 1).

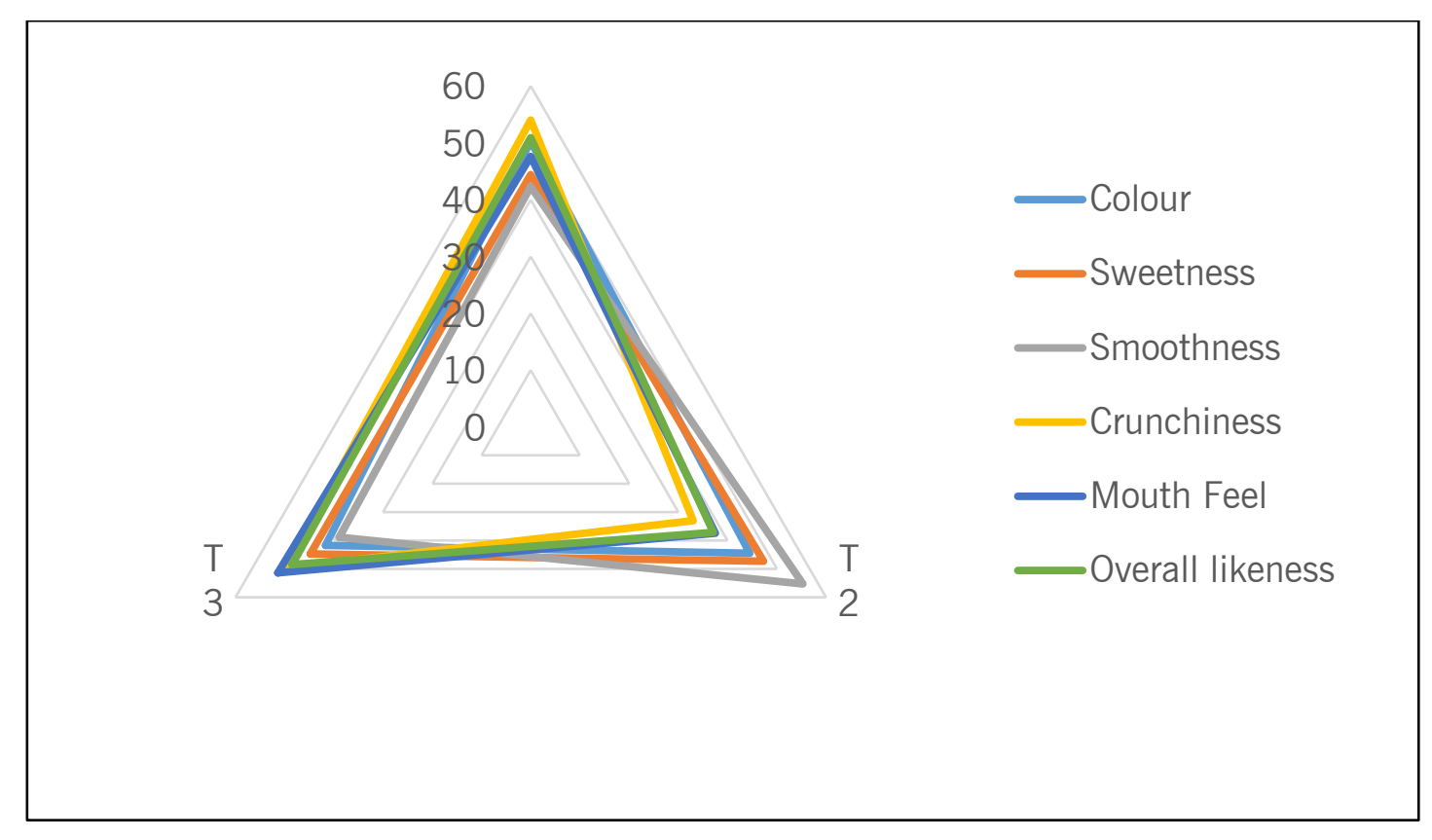

Figure 1: Sensory profile developed by panellists' score for the attributes of each treatment 


\section{Phytochemical Screening of Herbal Cookie Sample}

Qualitative phytochemical screening of herbal cookies indicated the presence of alkaloids, saponins, flavonoids, tannins, phenols, terpenoids, glycosides, and steroid while only the negative response implied the absence of anthraquinones (Table 2). The methanol extract was used as the control.

Table 2: Phytochemical constituents of the powdered herbal cookies

\begin{tabular}{cc}
\hline Phytochemical & Results \\
\hline Alkaloids & + \\
Saponins & + \\
Flavonoids & + \\
Tannins & + \\
Phenols & + \\
Terpenoids & + \\
Glycosides & + \\
Anthraquinones & - \\
Steroids & +
\end{tabular}

Presence of the compound (+), absence of the compound (-)

\section{Determination of Physicochemical Characteristics}

pH and Titratable Acidity

The $\mathrm{pH}$ is an important parameter in the formulation of biscuits. The result of the $\mathrm{pH}$ and TTA of herbal powder incorporated wheat flour are presented in Table 3. The $\mathrm{pH}$ and TTA values were ranged from $6.0 \pm 0.05$ to $6.1 \pm 0.05$ and $0.347 \%$ to $0.383 \%$ respectively during the storage period of cookies. The $\mathrm{pH}$ of the most bakery products was ranged from 3.5 to 8.0. And also, the $\mathrm{pH}$ of the most biscuits was ranged from 7.0 to 7.2 (BAKERpedia, 2019). The low TTA and $\mathrm{pH}$ in the cookies may be due to the departure of volatile acidity and organic compounds during baking (Akoja and Coker, 2018). Even though the acidity was higher than the reported biscuits, acidic products were more shelf-stable than nonacidic counterparts and an acidic $\mathrm{pH}$ was associated with the development of a pleasant taste (Ikechukwu et al., 2017). Therefore, the selected cookie formula was more shelf-stable.

\section{Peroxide Value}

It can be seen that the peroxide values of the cookie sample tend to increase gradually as the number of storage days increased from day 1 to day 14 (Table 4). As shown by Showkat et al. (2018), in our study also, the application of mungbean flour along with wheat flour has slightly reduced the rancidity level (peroxide value) between the day 10 to day 14 (Showkat et al., 2018). Oxidation processes are of particular significance in cookies as they contain a high amount of fat (Rinku et al., 2017). Overall, the peroxide value was found to be increased from $7.164 \pm 0.25 \mathrm{meqO}_{2} / \mathrm{kg}$ to $7.919 \pm 0.15 \mathrm{meqO}_{2} / \mathrm{kg}$. This increase might be due to the oxidation of unsaturated fatty acids in the oil. This was in complement to the fact that the higher substitution of mungbean flour which will practically reduce the peroxide value due to the improvement of stability toward oxidation 
Table 3: $\mathrm{pH}$, titratable acidity, moisture content and microbial analysis of herbal cookies during storage

\begin{tabular}{cccccc}
\hline $\begin{array}{c}\text { Storage } \\
\text { Time } \\
\text { (Week) }\end{array}$ & $\begin{array}{c}\text { Average } \\
\mathbf{p H} \\
\left(\mathbf{2 5} \mathbf{5}^{\circ} \mathbf{C}\right)\end{array}$ & $\begin{array}{c}\text { Titratable } \\
\text { acidity \% } \\
\mathbf{( T T A ~ \% )} \\
(\mathbf{m e q} / \mathbf{1 0 0 g})\end{array}$ & $\begin{array}{c}\text { Total plate } \\
\text { count } \\
(\mathbf{C F U} / \mathbf{g}) \times \\
\mathbf{1 0}^{\mathbf{2}}\end{array}$ & $\begin{array}{c}\text { Yeast and } \\
\text { mold count } \\
\mathbf{( C F U / g )}\end{array}$ & $\begin{array}{c}\text { Moisture } \\
\mathbf{\%}\end{array}$ \\
\hline 0 & - & - & $2.6 \pm 0.08$ & Not Detected & 5.9 \\
1 & $6.0 \pm 0.05$ & $0.383 \pm 0.002$ & - & - & - \\
2 & $6.1 \pm 0.05$ & $0.365 \pm 0.005$ & - & - & - \\
3 & $6.0 \pm 0.05$ & $0.347 \pm 0.001$ & $3.6 \pm 0.05$ & Not Detected & 5.0 \\
6 & - & - & $6.0 \pm 0.05$ & Not Detected & 4.2 \\
\hline
\end{tabular}

Each value is expressed as mean \pm standard deviation $(n=3)$

(Uthumporn et al., 2014). Therefore, the peroxide value of herbal cookies was within the range throughout 15 days of storage and it was within the standard of 10 meqO$_{2} / \mathrm{kg}$ reported for herbal biscuit (Srivastava and Raman, 2017).

Table 4: Effect of storage of herbal cookies on peroxide value

\begin{tabular}{cc}
\hline $\begin{array}{c}\text { Storage } \\
\text { period (Days) }\end{array}$ & $\begin{array}{c}\text { Peroxide Value } \\
\left.\text { (meq O }_{2} / \mathbf{k g}\right)\end{array}$ \\
\hline Fresh & $7.164 \pm 0.25$ \\
07 & $7.907 \pm 0.26$ \\
14 & $7.919 \pm 0.15$ \\
\hline
\end{tabular}

Each value is expressed as mean \pm standard deviation $(n=3)$

\section{Proximate Composition of the Cookies}

The level of moisture, ash, total fat, fiber, carbohydrate and protein content of the developed herbal cookies are in the range of USDA National Nutrient Database for Standard Reference (USDA Food Composition Databases, 2019). Akoja and
Coker (2018) reported that moisture content was an indicator of shelf stability, thus an increase in moisture content can enhance microbial growth which leads to deterioration in foods. The moisture content $(6.0 \%)$ of the product was lower than the range recommended by USDA National Nutrient Database for Standard Reference which is $11.5 \%$. The low moisture content of the herbal cookies reduced the possibility of microbial attack. High moisture content is not desirable in a product such as biscuits, because it has an inverse relationship with the texture of the product, which is an important attribute with consumer preference (Akoja and Coker, 2018). Taste and flavor of cookies are directly associated with the amount and quality of fat (Upadhyay et al., 2017). The total fat content of the cookies (14.3\%) was within the range of standard value reported by USDA which is $24.4 \%$ (Table 5). According to Banusha and Vasantharuba. (2014), the protein content of cookies is only $11.5 \%$ including $100 \%$ wheat flour compared to the protein content in herbal 
cookies (Table 5). The increase in protein content might be due to the appreciable amount of protein present in mungbean powder (Showkat et al., 2018). Because, mungbean powder contains the highest percent of protein according to the literature (Swaminathan et al., 2012). Therefore, herbal cookies enriched with the composite mungbean flour can serve as a cheap source of protein to the consumers (Akoja and Coker, 2018). The crude fiber content (3.3\%) was also slightly higher than the recommended value of $2.1 \%$ by USDA (Table 5). This may be due to greater fiber present in herbal plant powder and mungbean powder. The increased fiber content aids good bowel movement and it is necessary for foods generally as it reduces food retention time in the digestive tract (Akoja and Coker, 2018). A slight increase in ash content (3.7\%) of the product compared to the standard value of $3.3 \%$ shows that herbal plant powder increases the ash content in the cookies. This also might be due to the mineral content present in mungbean powder (Showkat et al., 2018). Ash content of a food material is a non-organic compound containing mineral content of the food. Nutritionally, it aids in the metabolism of other organic compounds such as fat and carbohydrates (Akoja and Coker, 2018). This might be due to the mineral content present in mungbean powder (Showkat et al., 2018). The carbohydrate content (59.3\%) of the herbal cookies is slightly higher than the standard value of USDA which is 58.15\% (Table 5). Herbal cookies consisted of carbohydrates that may contributed from wheat flour and mungbean flour. The increased value is not as high as $67.67 \%$ of carbohydrate reported by Banusha and Vasantharuba (2014) who have used $100 \%$ wheat flour.

\section{Calorific Value}

The reported calorific value for $100 \%$ wheat flour cookies is $402.9 \mathrm{kcal}$ (Omran et al., 2016). The calculated calorific value for the

Table 5: Proximate composition of herbal cookies produced from wheat flour and enriched with mung bean flour

\begin{tabular}{lccc}
\hline Parameter & $\begin{array}{l}\text { Herbal } \\
\text { cookies } \\
\text { (\%) }\end{array}$ & $\begin{array}{c}\text { USDA standard for } \\
\text { cookies (\%) (USDA Food } \\
\text { Composition Databases, } \\
\text { 2019) }\end{array}$ & $\begin{array}{l}\text { Wheat flour biscuit } \\
\text { (\%) (Banusha and } \\
\text { Vasantharuba, 2014) }\end{array}$ \\
\hline Crude Protein (\%) & $13.4 \pm 0.18$ & 8.92 & $11.5 \pm 0.5$ \\
Ash (\%) & $3.7 \pm 0.06$ & 3.3 & $1.10 \pm 0.12$ \\
Moisture (\%) & $6.0 \pm 0.06$ & 11.5 & $5.85 \pm 0.25$ \\
Crude Fiber (\%) & $3.3 \pm 0.28$ & 2.1 & $0.15 \pm 0.04$ \\
Total Fat (\%) & $14.3 \pm 0.12$ & 24.4 & $19.49 \pm 0.38$ \\
Carbohydrate (\%) & $59.3 \pm 0.33$ & 58.15 & $67.67 \pm 0.38$ \\
\hline
\end{tabular}

Each value is expressed as mean \pm standard deviation $(n=3)$ 
herbal cookies was $419.5 \mathrm{kcal}$. The energy values which is the total available energy in any food samples are ranged from 455.15 to 419.06 kcal (Akoja and Coker, 2018). According to USDA standard, commercially prepared cookie enriched with butter includes $467 \mathrm{kcal}$ (USDA Food Composition Databases, 2019). Therefore, the developed herbal cookie enriched with mungbean flour secure a considerable amount of carbohydrate, protein and fat compared to the cookies consisted of $100 \%$ wheat flour.

\section{Analysis of Antioxidant Activity (DPPH Radical Scavenging Assay)}

DPPH is a highly stable free radical with purple color. After reacting with an antioxidant it turned to a stable yellow color compound (diphenyl-picrythydrazine). Reduction in the color was measured by spectrophotometer as reported by Kumar et al. (2013). The IC50 value for the methanol extract of the herbal cookie was found to be $16.69 \mathrm{mg} / \mathrm{ml}$ (Table 6). Compared to the IC50 value of ascorbic acid, the IC50 value of the product is higher which means the herbal cookies have lower scavenging activity than the ascorbic acid. The IC50 value of the aqueous extract of Aerva lanata is $5.25 \mathrm{mg} / \mathrm{ml}$ which means the herbal cookies have lower scavenging activity than the aqueous extract of Aerva lanata and similar results are reported by Jayathilake $e t$ al. (2016). It seems that the scavenging activity has been decreased when the plant is incorporated into the cookies. On the other hand, the plant extract was found nontoxic towards human erythrocytes in the hemolytic assay where the IC50 value of the plant extract was $24.89 \mathrm{mg} / \mathrm{mL}$ (Kumar et al., 2013). These results concluded that the A. lanata stem incorporated into herbal cookies possesses an acceptable and considerable amount of antioxidant activity which can aid in the treatment of degenerative diseases such as cancer and diabetes (Jayathilake et al., 2016).

Table 6: IC50 values of different samples in DPPH scavenging assay

\begin{tabular}{cc}
\hline Type of samples & IC50 value \\
\hline $\begin{array}{c}\text { Herbal cookie } \\
\text { sample }\end{array}$ & $16.69 \pm 0.88 \mathrm{mg} / \mathrm{ml}$ \\
Ascorbic acid & $21.23 \pm 0.62 \mu \mathrm{gg} / \mathrm{ml}$ \\
(Reference) & \\
Aqueous extract of & $5.25 \pm 0.91 \mathrm{mg} / \mathrm{ml}$ \\
Aerva lanata & \\
\hline
\end{tabular}

\section{Microbial Analysis}

\section{Total Plate Count and Mold Count}

The total plate count of herbal cookies was found to be increased with the storage period of the cookie sample. The highest TPC was observed at the end of the $6^{\text {th }}$ week as $6.0 \times 10^{2} \mathrm{CFU} / \mathrm{g}$ (Table 4). The safe level of bacterial count for cookies should be below $1 \times 10^{4} \quad \mathrm{CFU} / \mathrm{g}$ (Banusha and Vasantharuba, 2014). Therefore, it seems that the product could be acceptable for future consumption.

Yeast and molds were not detected in the product throughout the storage of 6 weeks at one week interval. It might be due to the thermal processing, low water 
activity and hygienic practices followed during processing as reported by Agrawal et al. (2017).

\section{Shelf Life Determination}

It shows that the moisture content of herbal cookies has decreased over 6 weeks of storage (Table 4). It may be due to the decrease in fat content or sugar content with the storage period (Upadhyay et al., 2017). However, moisture content was within the standard range specified by USDA which was 4-5\% (USDA Food Composition Databases, 2019). Therefore, the microbial activity has been minimized since the moisture is essential for the growth of microorganisms. According to microbial analysis and the moisture content, it indicated that the microbial counts were within the accepted range and cookies made in this study were safe to consume after storing it for 6 weeks.

\section{CONCLUSION}

The results of this study revealed that the incorporation of young stems, leaves and flowers of Aerva lanata and Asparagus racemosus fine plant powder together with mungbean (Vigna radiata) flour significantly improved the nutritional, sensorial quality, microbial stability, herbal value and antioxidant activity of cookies compared to the traditional wheat flour biscuit. Qualitative phytochemical screening for the acceptable cookie treatment showed that the product contained phytochemicals such as Alkaloids, Saponins, Flavonoids, Tannins,
Phenols, Terpenoids, Glycosides, and steroid which may play roles in anti-cancer, anti-diabetic and anti-inflammatory in the human body.

The $\mathrm{pH}$ and TTA values during the storage period of cookies indicated to be more shelf-stable. Peroxide value significantly increased with the increase in storage period, though still, it was lower than the maximum recommended level and thus safe to consume. The level of moisture, ash, total fat, fiber, carbohydrate and protein content of the developed herbal cookies were in the acceptable range and a higher amount of carbohydrate, protein and fat is caused for the richness in energy value of cookies. The A. lanata stem incorporated into herbal cookie possesses acceptable and considerable amount of antioxidant activity which can aid in the treatment of many chronic diseases. Microbial study showed that the microbial counts were within the accepted range and cookies made were safe to consume. Hence, it was concluded that cookies supplemented with herbal plant powder enriched with mungbean flour can be stored safely in low-density zip lock polythene under room temperature for 6 weeks without any adverse changes in the organoleptic traits.

\section{REFERENCES}

Agrawal, R., Shirale, D. and Syed, H. (2017). Effect of Storage on Quality Evaluation of Cookies Supplemented with Germinated Fenugreek Seed Powder. International Journal of 
Advanced Biological Research, 7(3): 630-633.

Akoja, S. and Coker, O. (2018). Physicochemical, Functional, Pasting and Sensory Properties of Wheat Flour Biscuit Incorporated with Okra Powder. International Journal of Food Science and Nutrition, 3(5): 64-70.

AOAC, (2006). Official Methods of Analysis. 15th edition, Association of Official Analytical Chemists, Washington DC, 78-90 pp.

BAKERpedia, (2019). Baking Processes. Available online at https://bakerpedia.com/processes/ph/ (Accessed 21st March 2019).

Banusha, S. and Vasantharuba, S. (2014). Preparation of Wheat-Malted Flour Blend Biscuit and Evaluation of its Quality Characteristics. AmericanEurasian Journal of Agricultural and Environmental Science, 14(5): 459-463. Gunasekera, L. (2015). Hathawariya Queen of Herb - Valuable Medicinal Plant - Sri Lanka Guardian. Available from

https://www.slguardian.org/hathawariy a-queen-of-herb-valuable-medicinalplant/ (Accessed 21st March 2019)

Grah, A.M., Beugre M., Yapo Beda P., Dakia Aubin, K.P.V. and Niaba, D.G. (2014). Manufacture of Biscuit from the Flour of Wheat and Lentil Seeds as a Food Supplement. European Journal of Food Science and Technology, 2: 23-32. Ikechukwu, P., Okafor, D., Kabuo, N., Ibeabuchi, J., Odimegwu, E. and Alagbaoso, S. (2017). Production and Evaluation of Cookies from Whole Wheat and Date Palm Fruit Pulp as
Sugar Substitute. International Journal of Advancement in Engineering Technology, Management and Applied Science, 4(4): 1-31.

Jayashree, G., Rachitha, P., Krupashree, K., Kumar, H. and Khanum, F. (2013). Phytochemical Analysis of Methanolic Extract of Roots of Asparagus racemosus (Shatavari). International Journal of Pharma and Bio Sciences, 4(4): 250 - 254.

Jayathilake, C., Rizliya, V. and Liyanage, R. (2016). Antioxidant and Free Radical Scavenging Capacity of Extensively Used Medicinal Plants in Sri Lanka. Procedia Food Science, 6: 123-126.

Kajala, I., Shi, Q., Nyyssölä, A., Maina, N., Hou, Y. and Katina, K. (2015). Cloning and Characterization of a Weissella confusa Dextransucrase and its Application in High Fibre Baking. Plos One, 10: e0116418.

Kirk, R., Sawyer, R., Pearson, D. and Egan, H. (1991). Pearson's Composition and Analysis of Foods. 8th Edition, Harlow: Longman Scientific \& Technical, 223 pp.

Kumar, G., Karthik, L. and Rao, K. (2013). Phytochemical Composition and In Vitro Antioxidant Activity of Aqueous Extract of Aerva lanata (L.) Juss. ex Schult. Stem (Amaranthaceae). Asian Pacific Journal of Tropical Medicine, 6(3): 180-187.

Oeung, S., Nov, V., Ung, H., Roum, K., Yin, V. and Chea, S. (2017). Phytochemical Analysis of Different Extracts of Leaves of Nicotiana tabacum L. of Cambodia. Asian Journal of Pharmacognosy, 1(3): 18-26. 
Omran, A., Ibrahim, O. and Mohomed, Z. (2016). Quality Characteristics of Biscuit Prepared from Wheat and Flaxseed Flour. Advances in Food Sciences, 38(4): 129-138.

Rinku, R., Shirale, D. and Syed, H. (2017). Effect of Storage on Quality Evaluation of Cookies Supplemented with Germinated Fenugreek Seed Powder. International Journal of Advanced Biological Research, 7(3): 630-633.

Robert F. (1998). Liliaceae - Famine Foods. Centre for New Crops and Plant Products, Department of Horticulture \& Landscape Architecture, Purdue University. Journal of Ethnopharmacology, 18: 273-296.

Showkat, S., Dar, A., Khan, S. and Gani, M. (2018). Effect of Mungbean and Rice on Physico-Chemical, Sensory and Microstructural Properties of Cereal Bars. Carpathian Journal of Food Science and Technology, 10(4): 70-78.

Sri Lanka Standards (1988). Determination of Water-Soluble Ash Content, ISO 1576:1988, Sri Lanka Standards Institution, Colombo, Sri Lanka.

Sri Lanka Standards (2007). Specification for Dried fish, SLS 643:2007, Sri Lanka Standards Institution, Colombo, Sri Lanka.

Sri Lanka Standards (2008) Sri Lankan Standard for Microbiological Analysis, the Pour Plate Method Described by ISO 21527-2: 2008 for the Yeast and Mold count, Sri Lanka Standards Institution, Colombo, Sri Lanka

Sri Lanka Standards (2013) Sri Lankan Standard for Microbiological Analysis,
SLS 516: Part 1- Part 6: 2013 for Total Plate Count, Sri Lanka Standards Institution, Colombo, Sri Lanka

Srivastava, K. and Raman, M. (2017). Formulation and Standardization of Protein Rich Herbal Biscuits. International Journal of Current Science Research, 3(4): 1229-1237.

Swaminathan, R., Singh, K. and Nepali, V. (2012). Insect Pests of Green Gram Vigna radiata (L.) Wilczek and Their Management. Agricultural Science, 10: 198- 219.

Thorat, P., Sawate, A., Patil, B. and Kshirsagar, R. (2017). Proximate and Phytonutrient Content of Cymbopogon citratus (Lemongrass) Leaf Extract and Preparation of Herbal Cookies. International Journal of Chemical Studies, 5(6): 758-762.

Upadhyay, S., Khan, S., Tiwari, R., Kumar, S., Kohli, D. and Rautela, I. (2017). Nutritional and Sensory Evaluation of Herbal Cookies. International Journal of Food Science and Nutrition, 2(6): 156-160.

USDA Food Composition Databases, (2019), Bakery Items, Desserts and Crackers. Available online at https://fdc.nal.usda.gov/ (Accessed 22nd September 2019).

Uthumporn, U., Woo, W., Tajul, A. and Fazilah, A. (2014). Physico-Chemical and Nutritional Evaluation of Cookies With Different Levels of Eggplant Flour Substitution. CyTa - Journal of Food, 13(2): 220-226. 